\title{
THE DETERMINANTS OF INDIAN FDI IN AFRICA: A STRUCTURAL \&PUATION APPROACH
}

\author{
Henri Bezuidenhout* \\ North West University \\ Henri.bezuidenhout@nwu.ac.za \\ Susanna Cloete+ \\ Carike Claassen" \\ North West University \\ North West University \\ 21083657@nwu.ac.za \\ Carike.claassen@nwu.ac.za
}

Received: August 2013

Accepted: March 2014

\begin{abstract}
Much has been written in economic circles about the rising investment of the BRICS countries in Africa, yet there is scant literature on the determinants of FDI from these countries to Africa, and no studies have reported on that from India. In 2012, Indian FDI surpassed that of China, making India the largest developing country that is a direct investor in Africa. This study focuses on understanding the determinants of Indian FDI in Africa using structural equation modelling (SEM), which includes factor analysis and regression estimations. The specific determinants that influence the number of Indian FDI deals in Africa include government effectiveness, control of corruption, crude oil price, school enrolment and exports. The value of the investments is influenced by government effectiveness and rule of law. We conclude that India's increasing involvement in Africa is driven by trade and resources. It is, however, differentiated through a strong focus on good governance.
\end{abstract}

Keywords

Foreign Direct Investment, Africa, India, Structural Equation Model

*Dr H Bezuidenhout is a senior lecturer in the School of Economics at the North West University, South Africa.

\#Ms SE Cloete is a student in the School of Economics at the North West University, South Africa.

*Ms C Claassen is lecturer in the School of Economics at the North West University, South Africa. 


\section{INTRODUCTION}

The current economic debate regarding development in Africa is fuelled by the growing influence of the BRICS (i.e. Brazil, Russia, India, China, South Africa) countries across Africa and the perceived threat they pose to the historical investors such as the United States, the United Kingdom, France, Germany and Japan. At the forefront of this debate is the role of FDI by these countries. A decade ago, none of these countries were viewed as important investors in Africa. Today, China and India have risen to become two of the top five investors in Africa, with India surpassing China to become the number four investor in 2012 (Financial Times, 2012).

According to Broadman (2011), most research focuses on Chinese involvement in Africa. Countries such as India and Brazil are mostly omitted from studies on investment in Africa, although these countries also have extensive interests in Africa. Studies focusing on the rise of BRICS investment in Africa are scarce, especially India, and therefore this study further investigates the rise of Indian FDI in Africa.

Growing collaboration between India and Africa was signalled by the inaugural Indo-African Forum Summit in New Delhi in 2008. Its core focus was India's interest in Africa. India is striving to change the perception the world has of it by becoming more of a development donor than a recipient (Kragelund, 2010). At this first summit, issues such as agriculture, trade, industry, investment, peace and security, good governance and information technology were discussed (Bhatt, 2008). During this summit, it also became clear that the main objective is the expansion of South-South cooperation between equal partners.

Africa's ability and need for development have proved to be a great opportunity for India and its prospects, since the African image of war and poverty has been superseded by many seeing Africa as an opportunity with great promise as well as a growing economy. This is supported by Clark's (2012:16) statement that 'Most economic interpretations of the past and present presume that "Africa is poor". Not true. Africa is not really "poor" as portrayed: it is poorly managed and yet to be developed. Its inherent natural wealth is yet to be fully unlocked, leading many to expect a better future, and there is promise in this direction'. Several African countries are among the fastest-growing economies in the world, which are boosted by FDI with high riskadjusted returns (PricewaterhouseCoopers, 2011) Africa's increase in demand for investment opportunities has led to tremendous changes and growth. The United States and United Kingdom are still the largest providers of FDI in Africa, but the emerging Asian markets have become significant players in FDI to Africa (Price Waterhouse Coopers, 2011).

This study focuses on understanding the determinants of Indian FDI in Africa by profiling these determinants through a review of literature and using structural equation modelling (SEM) to establish the specific determinants. The rest of the paper consists of a literature review, an overview of Indian FDI in Africa, a discussion on the data used and the data limitations, the method used, and estimation results, where after the paper is concluded.

\section{LITERATURE REVIEW}

Some researchers aver that FDI can play a significant role in economic development and integration. Other researchers argue that FDI is harmful to local markets and has the risk of only extracting natural resources without developing the country (OECD, 2008; Stefanović, 2008). The state of FDI flows and stock between and in countries has undergone changes, and has received 
scrutiny, opposition and support. World trends in FDI flows demonstrate large shifts to emerging markets. These shifts have motivated new research to examine FDI and possible effects and causes (Sauvent et al., 2009). FDI is broadly split into two methods of entry, namely Greenfields FDI and Mergers and Acquisitions (M\&As). Greenfield FDI entails a new venture that requires new operational facilities to be established, while an M\&A is the acquisition of a significant executive share in an existing enterprise in the host economy (Investopedia, 2013).

The reasons and motivations for multinational enterprises (MNEs) to invest are supported by the different types of FDI. Market-seeking FDI, resource-seeking FDI and efficiency-seeking FDI are the main types of FDI. Market-seeking FDI indicates MNEs that obtain market access in a foreign market; market-seeking FDI can replace local domestic capabilities in regions; and resourceseeking FDI involves MNEs that require certain resources that are available in foreign markets. Nigeria - an oil-rich country - is a good example, attracting plenty of resource-seeking FDI. It has significant growth and increasing FDI flows that are for the most part motivated by resource-seeking FDI (Te Velde, 2006). Efficiency-seeking FDI focuses on assembling the best and most affordable production process factors, and can transform production structures and therefore the growth performance of firms.

FDI inflows are affected and determined by a variety of factors and risks. The determinants can be divided into two classification groups, i.e. micro- and macro-economic factors (Naude \& Krugell, 2003). The micro-economic determinants include market size and growth, labour cost, host government policies, tariffs and trade barriers, taxes, transport cost, agglomeration effects and environmental factors. The macro-economic factors include openness and exports, exchange rates, inflation, budget deficits, investment and infrastructure, political instability and natural resource availability (Naude \& Krugell, 2003; Bezuidenhout, 2007).

The determinants are not the only influence on an investor's decision, according to White and Fan (2006). Risks also influence FDI flows. These can be classified as global, country, industry and enterprise risks. African markets are sensitive to these risks, especially to country or sovereign risk, which includes political considerations. These should be considered when the determinants of FDI are profiled.

Broadman (2011) and Katakey (2010) describe the need for resources by an ever-expanding Indian economy. Global resource prices or commodity prices therefore also warrant further investigation as determinants for Indian interests in Africa. To accommodate commodity influences, we include the following factors: agricultural prices, various metals prices (see TABLE 1) as well as the crude oil price as global factors.

TABLE 1 provides an overview of the different determinants of FDI and their categorisation as micro-economic, macro-economic, risk, political (good governance) and global factors. The specification of these categories of determinants distinguishes the behavioural patterns of Indian FDI in Africa on whether it is market-seeking, efficiency-seeking and/or resource-seeking FDI. 
TABLE 1: FDI determinant classification

\begin{tabular}{|c|c|c|c|c|c|}
\hline & Risk factors & $\begin{array}{l}\text { Macro- } \\
\text { economic } \\
\text { factors }\end{array}$ & $\begin{array}{l}\text { Micro- } \\
\text { economic } \\
\text { factors }\end{array}$ & Global factors & $\begin{array}{c}\text { Political factors } \\
\text { (good } \\
\text { governance) }\end{array}$ \\
\hline 1. & Tax policy risk & Infrastructure & $\begin{array}{l}\text { Market } \\
\text { growth }\end{array}$ & $\begin{array}{l}\text { Agricultural } \\
\text { prices }\end{array}$ & Political stability \\
\hline 2. & Security risk & $\begin{array}{l}\text { Market } \\
\text { openness }\end{array}$ & Price changes & Copper prices & $\begin{array}{l}\text { Government } \\
\text { effectiveness }\end{array}$ \\
\hline 3. & Political stability risk & Exchange rate & Level of skills & Crude oil price & $\begin{array}{c}\text { Voice and } \\
\text { accountability }\end{array}$ \\
\hline 4. & Macro-economic risk & Exports & Tax & Gold price & Regulatory quality \\
\hline 5. & Legal \& regulatory risk & $\begin{array}{l}\text { Budget } \\
\text { deficits }\end{array}$ & Labour cost & $\begin{array}{l}\text { Precious metals } \\
\text { price }\end{array}$ & Rule of law \\
\hline 6. & Labour market risk & $\begin{array}{l}\text { Political } \\
\text { stability }\end{array}$ & Market size & & $\begin{array}{l}\text { Control of } \\
\text { corruption }\end{array}$ \\
\hline 7. & Infrastructure risk & & $\begin{array}{l}\text { Government } \\
\text { policies }\end{array}$ & & \\
\hline 8. & $\begin{array}{l}\text { Government effectiveness } \\
\text { risk }\end{array}$ & & & & \\
\hline 9. & $\begin{array}{l}\text { Foreign trade \& payments } \\
\text { risk }\end{array}$ & & & & \\
\hline 10. & Financial risk & & & & \\
\hline
\end{tabular}

Source: Authors'own compilation (EIU, 2012; Blonigen, 2005; Bezuidenhout, 2007)

\section{OVERVIEW OF INDIAN FDI IN AFRICA}

Most FDI in Africa originates, or traditionally has originated, from a bouquet of the leading FDI source countries. During the past decade, Asian economies have become an essential source of investment in Africa. They form the bulk of FDI in the continent from developing countries. Countries such as China, India and Malaysia have become substantial sources of FDI in Africa, accounting for interregional FDI flows among developing countries. A large number of investments are resource-seeking. Although countries such as China and India are investors in sectors such as manufacturing and infrastructure globally (UNCTAD, 2010), questions remain as to the patterns of their investments in Africa.

FIGURE 1 places Indian FDI within an African context. During the period 2003 to 2012, India provided the fourth-largest share after the 'traditional investors', i.e. the United States, United Kingdom and France. Indian FDI also outstripped Chinese FDI. 


\section{Greenfields FDI in Africa 2003-2012: Selected Partners}

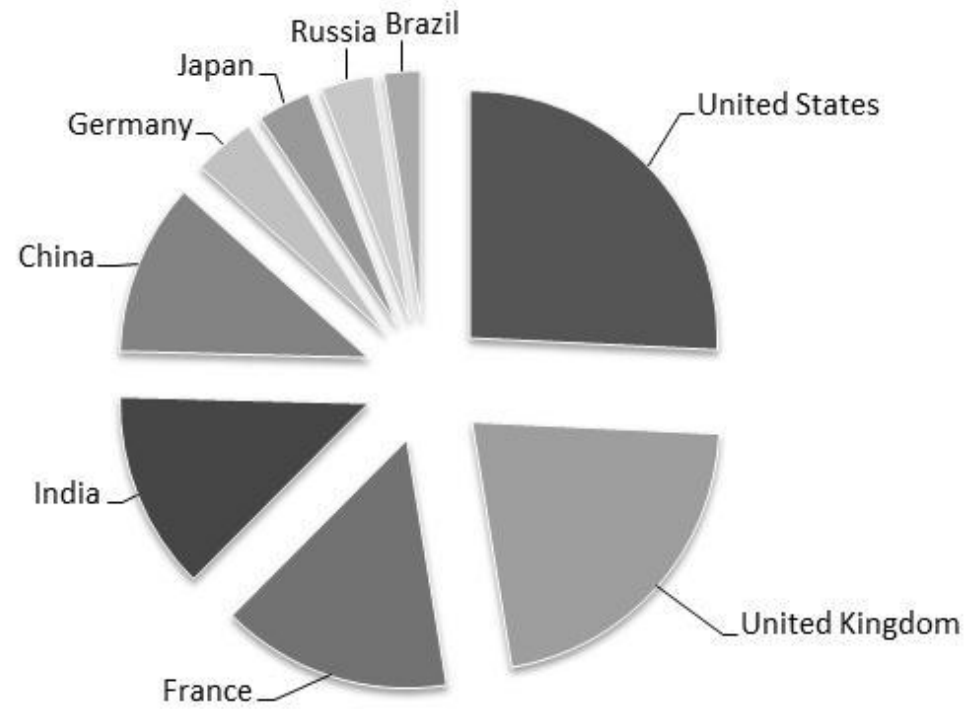

FIGURE 1: India's relative position as an FDI source country 2003 to 2012

Source: Financial Times (2012)

Between 2003 and 2012, India lagged the United States and the United Kingdom in FDI, but in most years surpassed China. In 2012, India was Africa's largest source of FDI (FIGURE 2).

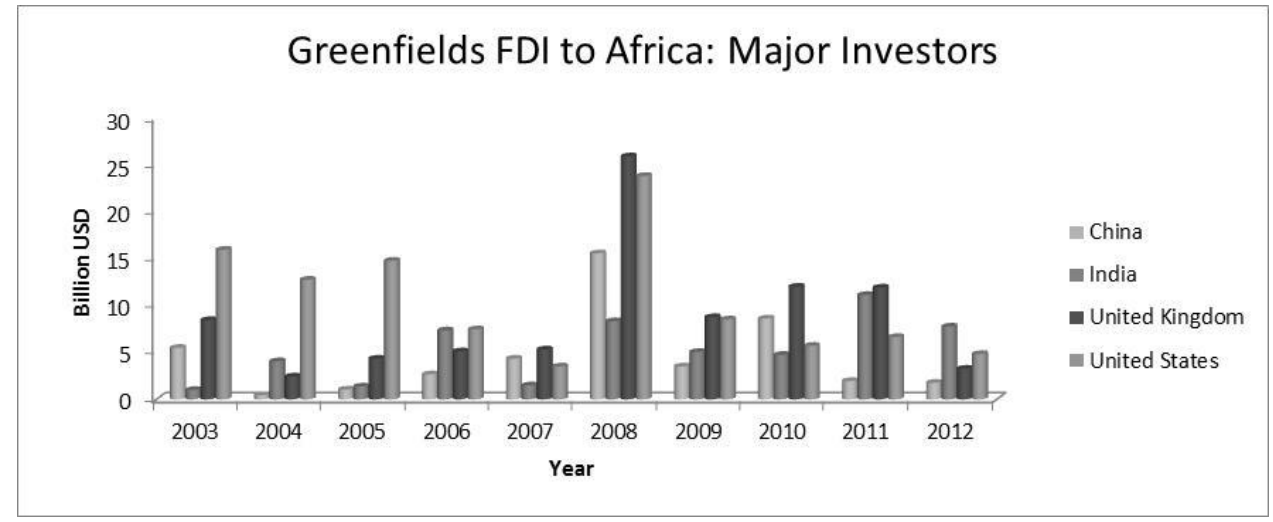

FIGURE 2: India's relative performance as an FDI source country 2003 to 2012

Source: $\quad$ Financial Times (2012) 
FIGURE 2 shows that overall FDI from India to Africa proportionately increased during the past decade and rose rapidly in 2011, reaching a high of US\$45 billion. FDI flows from India to Africa have expanded geographically, increasing by $837 \%$ over the period. Indian firms are doing business in over 32 African countries today (Financial Times, 2012). Bhattacharya (2011) states that the steep rise in Indian FDI to Africa clearly indicates that Indian companies see potential in the African market and that it may well be the market of the future.

African countries that received the most FDI from India are mostly those with high levels of development and larger GDP values. These countries are also among the top FDI recipients of FDI in Africa from across the globe. Nigeria receives most of India's Greenfields FDI to Africa, with the majority being in the coal, oil and gas sectors (Nyagah, 2009). Nigeria has abundant resources of oil, which is the reason it is expected to become one of the largest economies in the world. Large amounts of Indian FDI also flow to the chemical industry in Nigeria. Mozambique and Egypt also benefited from large Indian FDI inflows, the major sectors also including coal, oil, gas and chemicals (Nyagah, 2009). Zimbabwe's metal sectors attract the majority of Indian FDI in this country, while South Africa's coal, oil, gas and metal industries attract the most Indian FDI (Nyagah, 2009). The top five African countries that attract Indian Greenfields FDI are mainly those with abundant natural resources.

TABLE 2: Top 10 African FDI recipients from India, 2003-2012

\begin{tabular}{|c|c|c|c|c|}
\hline Rank & $M \& A$ & US\$ million & Greenfields & US\$ million \\
\hline 1 & Sudan & 0.76 & Nigeria & 10470 \\
\hline 2 & South Africa & 0.72 & Mozambique & 7125 \\
\hline 3 & Zambia & 0.50 & Egypt & 4228 \\
\hline 4 & Mauritius & 0.12 & Zimbabwe & 4068 \\
\hline 5 & Mozambique & 0.10 & South Africa & 3907 \\
\hline 6 & Tunisia & 0.07 & Kenya & 3702 \\
\hline 7 & Morocco & 0.04 & Zambia & 3206 \\
\hline 8 & Nigeria & 0.03 & Ghana & 1912 \\
\hline 9 & Kenya & 0.01 & Cameroon & 1907 \\
\hline \multirow[t]{2}{*}{10} & Togo & 0.01 & Ethiopia & 608 \\
\hline & Total & 3.239 & Total & 41133 \\
\hline
\end{tabular}

Sources: The Financial Times (2012) \& Bureau van Dijk Database (2012)

TABLE 2 further indicates that Sudan received the highest amount of Indian Mergers and Acquisitions (M\&A), with the majority going to the petroleum industry. M\&As taking place in South Africa are mainly in the metals and telecommunications industries. In Zambia, Indian firms have invested mainly in the telecommunication sector. Mauritius, a gateway for financial services, because of its low tax regime, has attracted Indian investment in machinery and financial services. Indian FDI in Mozambique is mainly to acquire hard-coal production.

Indian MNEs in Africa tend to be in the private firms; they prefer to acquire existing firms and help to encourage engagements in vertical integration improving the African socio-economic 
network (Broadman, 2011). Indian as well as Chinese firms have many similarities with regard to their African operations. The increasing presence of the Chinese and Indians in Africa seems to have a positive correlation with trade as shown by Africa's exports (Broadman, 2011).

TABLE 3 indicates that most of Indian FDI flows are to the natural-resource industries, such as petroleum, coal, oil and gas. Most of the mergers and acquisitions are in the resource sector, while the Greenfields FDI includes the private sector. The dominance of the sectors such as software, IT and telecommunication motivates the fact that India focuses on sectors in which it has a competitive advantage. These sectors are also to Africa's advantage since FDI may lead to knowledge as well as skills transfers into the African market.

TABLE 3: Top African sectors receiving FDI from India, 2003-2012

\begin{tabular}{|c|c|c|c|c|}
\hline Rank & $M \& A$ & USS million & Greenfields & US\$ million \\
\hline 1 & Extraction of crude petroleum & 0.76 & Coal, oil and natural gas & 22409 \\
\hline 2 & Other telecommunications activities & 0.70 & Chemicals & 7431 \\
\hline 3 & $\begin{array}{l}\text { Mining of other non-ferrous metal } \\
\text { ores }\end{array}$ & 0.35 & Metals & 5065 \\
\hline 4 & Mining of hard coal & 0.13 & Food \& tobacco & 2303 \\
\hline 5 & $\begin{array}{l}\text { Translation and interpretation } \\
\text { activities }\end{array}$ & 0.08 & Automotive OEM & 1402 \\
\hline 6 & $\begin{array}{l}\text { Manufacture of pharmaceutical } \\
\text { preparations }\end{array}$ & 0.07 & Communications & 1234 \\
\hline 7 & $\begin{array}{l}\text { Manufacture of other chemical } \\
\text { products }\end{array}$ & 0.07 & Alternative/Renewable energy & 875 \\
\hline 8 & $\begin{array}{l}\text { Manufacture of fertilisers and } \\
\text { nitrogen compounds }\end{array}$ & 0.04 & Hotels \& tourism & 824 \\
\hline 9 & Other manufacturing & 0.03 & Plastics & 757 \\
\hline 10 & $\begin{array}{l}\text { Television programming and } \\
\text { broadcasting activities }\end{array}$ & 0.03 & Software \& IT services & 525 \\
\hline & TOTAL & 2.25 & TOTAL & 42825 \\
\hline
\end{tabular}

Sources: The Financial Times (2012) \& Bureau van Dijk Database (2012)

Although most Indian and Chinese investments in Africa are based on natural resources, MNEs are diversifying into other sectors, including infrastructure, IT, software, services and telecommunications (Broadman, 2011). In 2010, a third of all acquisitions made in sub-Saharan Africa were made by Indian firms (Bureau van Dijk, 2012) in terms of the total value of deals. Indian companies prefer to enter the market via acquisitions, even though the value of Greenfields FDI exceeds them by far. Large investments have been made in the telecommunications industry - the Indian firm Bharti Airtel bought Zain Africa for US\$10.7 billion in 2010 (The Financial Times, 2012). The other notable large investments by Indian companies were companies such as Tata motors, the Mahindra Group, Cipla and Ashok Leyland 
that established themselves in Africa, and, very significantly, in the South African market (Schneidman \& Lewis, 2012).

The nature of Indian FDI can be summarised as resource-seeking FDI with a changing focus on market-seeking and efficiency-seeking FDI. Private sector firms are playing a more prominent role in Indian FDI flows than Chinese enterprises, which indicates less direct political influence. India is set to become the second-largest economy in the world and its increasing beneficial influence in Africa can be an advantage to the development and growth of African markets (Schneidman \& Lewis, 2012).

\section{DATA AND DATA LIMITATIONS}

Data for Indian FDI in Africa is not widely available. We use the Financial Times FDI Markets database for Greenfields FDI as a source of specific Indian FDI in African countries on a deal-bydeal basis. The data covered by the Financial Times database is all recorded FDI deals from 2003 to 2012 for all African countries. This implies an observation-based population rather than a time series.

The main limitations of the database are that some deals may not be recorded due to a lack of information and secondly the data cannot be compared to FDI totals regularly published by the World Bank and the IMF (this data is only recipient country totals and does not include source country information). It should also be pointed out that not all countries received Indian FDI every year and the vast majority of deals are skewed towards the coal, oil and natural gas and metals sectors. This limits the application of econometric techniques, as the short sample period and irregular investment intervals per country and sector (these generate missing values) will render time series sample size too small for satisfactory analysis. We use SEM to accommodate the nature of the data, by looking at the population of FDI deals.

Variables that reflect the determinants of Indian FDI are linked to each individual observation. Risk variables from the Economist Intelligence Unit (દIU) operational risk model and the World Bank development indicators are used as determinants. These variables are discussed in the Specification section later on in the article. The $\varepsilon I U$ model covers 42 African countries from 2006 to 2012, but only 22 from 2003 to 2005. The World Bank covers all African countries, although not all data is available for all African countries.

\section{METHODOLOGY}

Standard econometric techniques are not relevant to accommodate the data limitations and irregularity of FDI in country-specific settings. We have therefore introduced SEM to answer the research question of which determinants are significant for Indian FDI in Africa and to estimate their relevance. SEM is widely used in the behavioural sciences. It is a large-sample observationbased technique that allows a combination of factor analyses and regressions. SEM also allows for multiple dependent variables, whereas correlation between explanatory variables does not affect the results (Arbuckle, 2011). Another advantage of using SEM is that it is based on measurement of error, as opposed to regular regression, which assumes perfect measurement.

SEM is a confirmatory technique that requires a predetermined model specification based on theory, to be estimated in order to confirm the theory. It tests the measurement and structural 
relationship of variables simultaneously. The basis of a SEM model is covariance, which tests the strength of the association between the variables. This helps to explain the pattern of correlation among the variables in the model and explains as much of the variables' variance as possible. The use of observation-based data rather than time series makes SEM, as a general statistical modelling technique, more suited to estimate possible relationships between variables in this case (Pearl, 1998). The theoretical specification therefore consists of the theoretical determinants of FDI being factors to unobserved determinant categories such as micro- and macro-determinants, and the identified determinants being regressed on the number of FDI inflows and FDI value.

There are three different types of SEM specifications: confirmatory factor analysis (CFA), path analysis with observed variables, and path analysis with latent variables. This study uses the CFA method because it is more deductive than inductive. This implies that it is a more logical approach since it is a bottom-up strategy, which indicates that conclusions are derived empirically. A top-down approach is one where a conclusion is developed based on theory. The $S E M$ is estimated based on the theoretical model of the determinants of FDI. These models are the empirical part, and depending on the goodness of model fit, conclusions are derived from the empirical results (Arbuckle, 2011).

In this study, models are estimated to indicate factor groupings; factor analysis and SEM allow for correlation between the different factors (Pearl, 1998). We then further our investigation by estimating another set of models that determine the linear relationship between factor variables and FDI; these models also allow for correlation among the independent variables. Once we have established the relevant determinants for each of the groupings specified by theory, we include them in a final model where only the relevant factors are included and regressed against the number of deals and the investment value.

According to Arbuckle (2011), there are two main classes of model fit, namely absolute fit and relative fit. These classes enable the evaluation of the goodness of fit and the general acceptability of the findings. The absolute fit of the model can be established by evaluating the chi-square, the minimum discrepancy for the model based on chi-square (CMIN), root mean squared error of approximation (RMSEA) and goodness of fit (GFI) measures. These indices provide a clear perspective on the ability of a model to duplicate the covariance matrices. Two models are compared by observing the absolute fit as well as the relative fit. The relative fit of a model is established by a comparison between the theoretical model and a baseline model. The baseline model has a standard specification, with an assumption that there is no relationship among variables; therefore, the relative fit of a model will indicate whether or not the estimated model is better than one with no correlation between variables. The Normed Fit Index (NFI), Incremental Fit Index (IFI), the Comparative Fit Index (CFI), Bolen's Relative Fit Index (RFI) and its derivative the Tucker-Lewis Coefficient (TLI) are mostly used as further measures to indicate the relative fit of a model (Arbuckle, 2011, Pearl, 1998). The biggest limitation on using measures of fit in this study is linked to the recursive nature of the factor analysis, in which case the probabilities of the individual variables are also taken into account to ensure the correct specification.

\section{SPECIFICATIONS}

For the purposes of this study, we make a basic assumption that the number of FDI deals that each country receives includes a risk decision and a set of determinants, although the actual 
value of the FDI deal might depend on a completely different set of determinants. The value or level of the investment is determined by capital cost and the availability of capital inputs in the market and sector; each industry will have a different profile. These two FDI variables are used as the dependent variables in a regression to derive the determinants of Indian FDI in Africa.

To identify the determinants as accurately as possible, variable groups are established and processed in a factor analysis. This allows identifying the factors with the most significant influence and greatest weights more accurately. The variable groups consist of micro-economic, macro-economic, risk, political (good governance) and global factors. The factors that are identified in the factors analysis are those that are included to be tested as determinants of Indian FDI in Africa in the final model.

The risk factor analysis is conducted first in order to determine the main risk areas that require focus in the estimation of the determinants. The factor analysis is then expanded to a regression model that tests the structural relationship between the estimated determinants and the population of FDI deals as well as the value of FDI inflows. The determinants of Indian FDI are correctly identified by testing the relationships separately in the different variable groups. This allows for more accurate correlation between variables. By placing variables in an appropriate group, those that create instability in the model can be identified and removed from the analysis.

The empirical analysis is done in steps. Factor analysis removes factors with low weights that do not exercise a significant influence, whereas regression analysis identifies the variables that have a significant influence. The process that is followed allows for accurate results and eliminates problems with high correlation between variables, such as endogeneity.

TABLE 4 provides a detailed list of the variables used during the estimation process. These include the actual variables used to represent the theoretical determinants based on the FDI literature as discussed by Blonigen (2005), Naudé and Krugell (2003), Bezuidenhout (2007) and Asiedu (2002; 2006). Sources of variables are listed as The Financial Times: F (2012), Word Bank Development Indicators (WDI) (World Bank, 2012a), World Bank Good Governance Indicators (WGG) (World Bank, 2012b), World Bank Commodity Prices (WCI) (World Bank, 2012c) and the Economist Intelligence Unit (દIU, 2012).

\section{TABLE 4: List of variables used in estimation}

\begin{tabular}{lll}
\hline Variable & \multicolumn{1}{c}{ Variables used } & Source \\
\hline Risk factors & See Table l & EIU \\
Macro-variables & & \\
Infrastructure & Telephone lines (per 100 people) & WDI \\
Market openness & Trade (\% of GDP) & WDI \\
Market size & GDP (current US\$) & WDI \\
Exchange rate & Official exchange rate (LCU per US\$, period average) & WDI \\
Exports & Exports of goods and services (current US\$) & WDI \\
Budget deficit & Budget balance (\% of GDP) & WDI \\
Political stability & Political stability (world bank good governance data) & WGG
\end{tabular}




\begin{tabular}{lll} 
Micro-variables & & \\
Market growth & GDP growth (annual \%) & WDI \\
Price changes & Inflation, consumer prices (annual \%) & WDI \\
Market size & Population growth (annual \%) & WDI \\
Level of human skills & School enrolment, secondary (\% gross) & WDI \\
Tax & Budget revenue (\% of GDP) & WDI \\
Labour cost & Labour force participation rate, total (\% of total & WDI \\
Government policies & population age) & Rule of law (World Bank good governance data) \\
Global factors & See Table l & WGG \\
Political factors & See Table l & WCI \\
FDI & & WGG \\
\hline FDI value & Vulue of FDI deals & FDIMarkets \\
\hline
\end{tabular}

Source: Authors' compilation

Masca and Demirhan (2008) highlight the problematic nature of labour costs in FDI estimations, especially when dealing with multiple countries. No uniform variable exists for dealing with African labour costs. Labour force participation rates do not reflect cost directly, but together with skills, risk and growth give an indication.

\section{ESTIMATION RESULTS}

An iterative process is first used to investigate the different groupings of FDI determinants in order to derive a final specification model. Based on the limitations imposed by the data, the interpretation of results is deliberately conservative. The findings of the iterative process are reported in full in the Appendix and can be interpreted as follows:

All factor analysis models have a good fit, except for macro-economic factors.

The analysis of estimated risk factors indicates factors such as finance, government effectiveness, foreign trade and payment, infrastructure, labour force, legal and regulatory issues, and tax policy as notably influential. We conclude that the role of government and a country's financial position play a significant role in the decision on whether to invest. The 'good governance' factors represent a country's political climate. The variables found to be significant also include control of corruption, government effectiveness and rule of law.

The global estimates consist of prices of the different global commodities as indexed by the World Bank (World Bank, 2012b). Significant commodities in the factor analysis include maize, metals and minerals, crude oil, precious metals and agricultural commodities. On the other hand, the only commodity that indicates a significant influence on the FDI flows is the crude oil 
price. This implies the importance of oil in Africa. This fact also reinforces the conclusion that India's investment has a strong element of 'resource seeking'.

The significant macro-economic factors include the exchange rate, crude oil price, government effectiveness and exports. The regression model augments this to crude oil, government effectiveness and exports. This not only emphasises the importance of oil and good governance, but also highlights the 'market-seeking' element in the relevance of exports. Overall, the macroeconomic model has the worst fit and this indicated that macro-factors by themselves do not represent a significant influence; only when viewed with the other groups do they contribute.

The micro-economic variables explain the influence of industry and firm-level factors. Factor analysis found population growth and school enrolment to be the significant factors in the micro-economic cluster. These variables indicate the vital importance of the labour force size and human capital in a country, which emphasises an 'efficiency-seeking' element in Indian FDI to Africa.

The determinants identified as being significant among the variables are used to derive the final model. There are two models that are estimated: one is to identify the determinants that influence the Indian investor's decision to invest, which is illustrated by the number of deals taking place. The other model estimates the determinants that influence the value or scale of the investment from Indian firms.

FIGURE 3 illustrates the results of the final model that reflects the determinants of Indian FDI in Africa. These factors, which are estimated in each variable group, are included in the estimation; only the factors with a significant influence are included in the final model. The factors are identified in the factor analysis and regression model. The factors that are identified as significant determinants include government effectiveness, control of corruption, crude oil, school enrolment and exports. These determinants indicate a significant influence on the decision to invest. The figure also shows the high levels of covariance (arching bi-directional arrows) between the factors that would make estimation using other techniques less accurate.

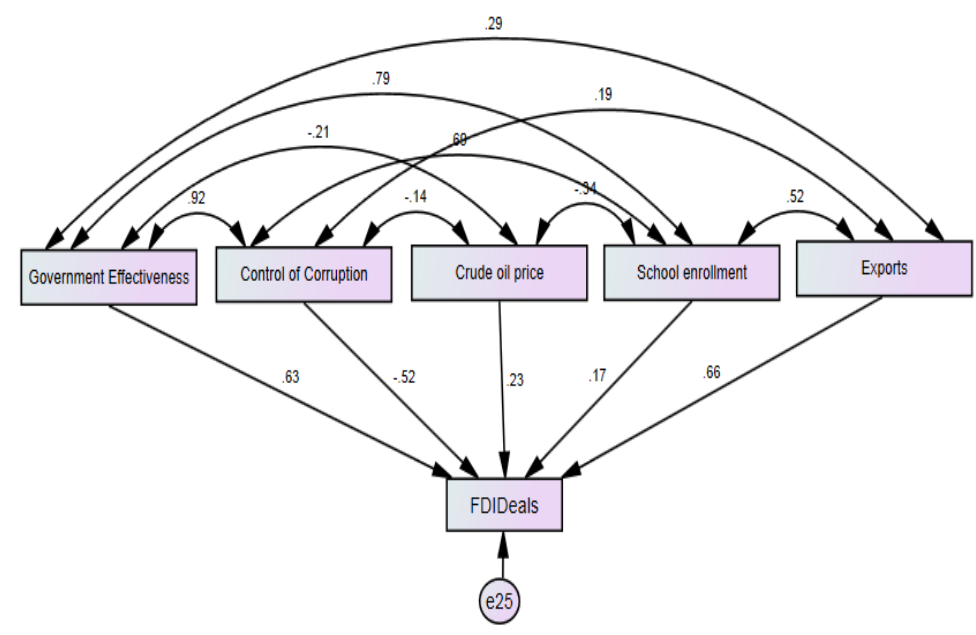

Figure 3: Final regression analysis output on the decision to invest

Source: $\quad$ Authors'calculations 
Government effectiveness has a relatively high positive coefficient that indicates that Indian firms tend to prefer more efficient political regimes. One could query the result on control of corruption, which has the only negative coefficient. The implication is that higher levels of corruption (a negative value) will lead to more deals. Different arguments can be made surrounding the statistical validity based on the severe data limitations. We suggest that the strong Indian investment in the coal, oil and gas sector, along with the reputation of the governments involved, provide enough of a counter-argument. A more in-depth sector study will resolve this issue once more data becomes available.

The relevance of the oil price as a determinant of Indian FDI advances the previous argument and confirms the strong investment repertoire of Indian firms in the coal, oil and gas sector. The oil price is a global determinant that cannot be controlled by African countries.

School enrolment and exports as determinants of Indian FDI extend our understanding of Indian multinational behaviour in that there is a significant distinction between resource-seeking FDI and both the efficiency-seeking and market-seeking forms of FDI, which require level of education and higher levels of trade. Exports are also seen as market seeking; this is important because it indicates the openness of the country, in other words, the manner in which a country interacts and operates with other nations.

TABLE 5: Model fit indications for regression on the amount of deals

\begin{tabular}{cccccc}
\hline Chi-Square & RMSEA & CMIN/DF & NFI & IFI & CFI \\
1.736 & 0.052 & 1.736 & 0.999 & 0.999 & 0.999 \\
\hline
\end{tabular}

Source: Authors' calculations

The measurements that are illustrated in Table 5 indicate a good-fitting model. A chi-square of 1.7 implies a good-fitting model and indicates that the covariance is close to the sample covariance. Given the weaknesses in the data, a zero value for perfect results cannot be expected. The RMSEA indicates a close-fitting model with a significant value that is close to 0 . $\mathrm{NFI}, \mathrm{IFI}$ and CFI values are above 0.9 , which indicates the model is a better fit than the default model with no correlation. The final model therefore indicates accurate interpretation and results, since it is accepted as having a good fit.
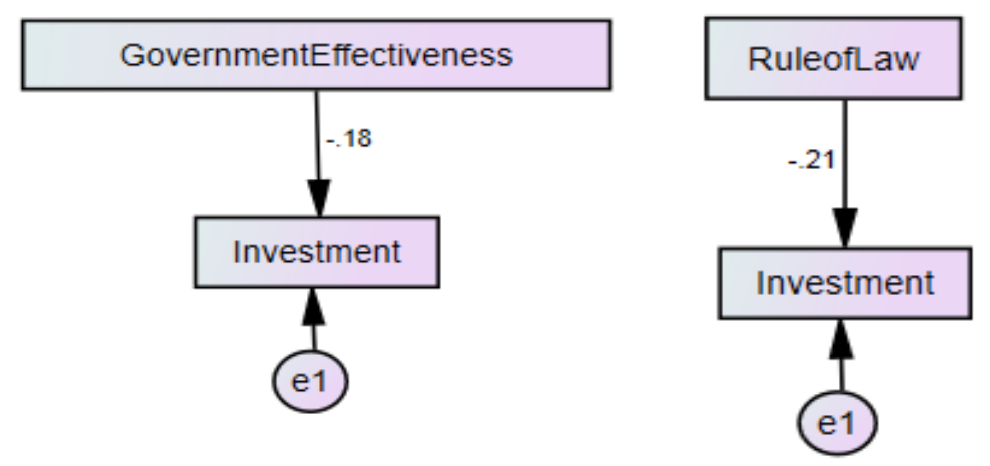

FIGURE 4: Final regression analysis output on the level of investment

Source: Authors'calculations 
The model that illustrates the determinants of the level or amount of FDI that Indian investors make is conducted in two parts. The variables indicate high covariance and similarity and therefore two separate models are estimated in order to determine a more accurate picture of the FDI flows. Both models are demonstrated in Figure 4. Both have negative coefficients that indicate that higher levels of efficiency and law enforcement negatively impact the level of investment. This confirms the arguments made previously regarding the oil, coal and gas sector.

The determinants of the level of investment are government effectiveness and rule of law. These determinants are highly correlated with one another and therefore estimated in separate models. Both determinants indicate a negative relationship: in other words, the higher the levels of adherence to political regulations the less an investor will invest. Nigeria, Algeria, Angola, Gabon and Equatorial Guinea represent the bulk of the oil sector investments that have negative indices values, which leads to the negative coefficient.

The political stability (risk) of an African country is indicated as being an important factor that influences an investor's decision on the amount to invest. The political status of African countries is rather weak and therefore a significant factor that needs attention and improvement in order to sustain FDI flows to Africa.

\section{CONCLUSION}

The objective of this study was specifically to explore the determinants of Indian FDI inflows into Africa. The intention was to determine, with the help of the literature and empirical evidence, an accurate profile of the specific determinants that are relevant in the debate regarding Indian FDI inflows into Africa. Very few studies exist on FDI flows to Africa, let alone determinants from developing countries.

We provide an empirical foundation to assess the relevant determinants of Indian FDI inflows to Africa. The primary result is that Indian firms are mostly attracted to effective, stable governments in efficiency-and market-seeking FDI; however, indications exist that large-scale investments in the oil, coal and gas sector prefer the opposite. This study furthermore makes a contribution to the scarce literature on FDI to Africa.

Speculation on the relativity of traditional determinants of FDI to Africa is extended to the sphere of developing countries investing in Africa. The results confirm that patterns differ from traditional patterns in the literature, with a strong emphasis on government actions to protect the investment and the exports of goods and services. We conclude that traditional determinants provide the overall framework for an investment decision concerning Africa, but a different approach is needed when investing in individual countries. The results obtained are of interest to African countries looking to attract FDI through favourable investment policies. African governments need to identify and implement sustainable policies on good governance, trade promotion and human skills development in order to strengthen their investment climate.

It can be concluded that if an Indian company considers investing in any African market the role of the recipient country's government is the single-biggest determinant, with government effectiveness, rule of law and control of corruption playing the most significant roles. Oil being a major area of investment for Indian firms in African markets indicates an important rule; this is mainly due to the high demand for oil in India due to its own shortage of the resource. The level of development in terms of the labour force in any African country indicates that a significant proportion of Indian FDI is efficiency seeking. The significance of exports indicates that the 
openness of a country is important for many Indian investors. The more exports take place, the better a country's ability to operate in a multi-stage international supply chain. This indicates a growing relevance for market-seeking FDI.

Recommendations for further research include a comparison with Chinese FDI and a further expansion to traditional partners. As more data becomes available, sectoral studies will become possible and should be pursued. Research could also be conducted on investment into individual African countries in order to gain an in-depth insight into which determinants of FDI inflows are significant to that country. Country analyses will provide a different insight from the general overview that was used in this study.

For a study involving many African countries, the major constraint is the availability of adequate data. Although the situation is changing with more and more international bodies and private entities collecting more specific data, the need still exists for African governments to produce more detailed and transparent data, especially data concerning M\&As and infrastructure projects.

\section{LIST OF REFERENCES}

Arbuckle, J.L. (2011). IBM SPSS Amos 20 user's guide.

Asiedu, દ. (2002). On the determinants of foreign direct investment to developing countries: Is Africa different? World Development, 30(1), pp. 107-119

Asiedu, $\varepsilon$. (2006). Foreign investment in Africa: The role of natural resources, market size, government policy, institutions and political instability. The World Economy, 29(1), pp. 63-77.

Bezuidenhout, H. (2007). Trade patterns and foreign direct investment in the Southern African development community. Unpublished PhD Thesis. Potchefstroom: North West University.

Bhatt, C.G. (2008). India and Africa unique historical bonds and present prospects, with special reference to Kutchis in Zanzibar. Working Paper No.5. University of Mumbai.

Bhattacharya, A. (2011). Africa: Why are Indian companies investing so fast? [Online] Available: http://www.ideasmakemarket.com/2011/06/africa-why-are-indian-companies.html. (Accessed 20 March 2012).

Blonigen, B.A. (2005). A review of the empirical literature on FDI determinants. Atlantic Economic Journal, 33, pp. 383-403.

Broadman, H.G. (2011) The backstory of China and India's growing investment and trade with Africa: Separating the wheat from the chaff. Columbia FDI perspectives, 34, pp. 1-3.

Bureau Van Dijk. (2012). Zephyr. [Online] Available: https://zephyr2.bvdep.com/version2013320/Home.serv?product=zephyrneo. (Accessed 7 July 2012).

Clarke, D. (2012). Africa's future: Darkness to Destiny. London: Profile Books.

Economic Intelligence Unit (EIU). (2012). The Economist. [Online] Available:

https://portal.eiu.com/login.aspx?service=http $\% 253 \mathrm{~A} \% 252 \mathrm{~F} \% 252 \mathrm{Fwww} \% 252 \varepsilon$ eiu $\% 252$ 2Ecom $\% 252 \mathrm{Fss}$ $0 \% 252$ Fcas $\% 252$ Fclient\&brand $=\&$ clientid $=4 \mathrm{~d} 5 \mathrm{~s} 333 \mathrm{q} 721$ os 21 \&gateway=true\&returnTo $=$ http $\% 253 \mathrm{~A} \% 25$ 2F\%252Fwww\%252Eeiu\%252Ecom\%252Findex\%252Easp\%253F. (Accessed 20 October 2012). 
Investopedia. (2013). Dictionary. [Online] Available:

http://www.investopedia.com/terms/g/greenfield.asp. (Accessed 12 May 2013).

Katakey, R. (2010). Indian oil invest in Africa \$1 Billion oversea push, chairman says. [Online]

Available: http://www.bloomberg.com/news/2010-07-15/indian-oil-to-buy-oilfields-in-africa-aspart-of-1-billion-overseas-push.html. (Accessed 20 July 2012).

Kragelund, P. (2010). India's African engagement. [Online] Available:

http://www.realinstitutoelcano.org/wps/portal/rielcano_eng/Content?WCM_GLOBAL_CONTEXT=/elca no/elcano_in/zonas_in/ari10-2010. (Accessed 20 July 2012).

Masca, M. \& Demirhan, દ. (2008). Determinants of Foreign Direct Investment Flows to Developing Countries: A Cross - Sectional Analysis. Prague Economic Papers, 4(1), pp. 356-369.

Naude, W.A. \& Krugell, W.F. (2003). Developing human resources to attract foreign direct investment in Africa. Management Dynamics, 12(3), pp. 2-12.

Nyagah, N. (2009). African markets making sense for India. [Online] Available:

http://www.tradeinvestafrica.com/feature_articles/256080.htm. (Accessed 15 February 2012).

Organization for Economic Co-Operation and Development. (2008). Benchmark definition of foreign direct investment. OECD Publications.

Pearl, J. (1998). Graphs, causality, and structural equation models. Sociological Methods \& Research, 27(2), pp. 226-284.

Price Waterhouse Coopers. (2011). 10 Minutes on investing in Africa, 1:8.

Sauvent, K.P., Maschek, W.A. \& Mcallister, G. (2009). Foreign direct investment by emerging market multinational enterprises: The impact of the financial crisis and recession and the challenges ahead. OECD Global Forum on International Investment. New York: OECD.

Schneidman, W. \& Lewis, Z.A. (2012). The African growth and opportunity act: Looking back, looking forward. Africa Growth Initiative at Brookings. Available:

http://www.brookings.edu/ /media/research/files/reports/2012/6/agoa/agoa_full_report.pdf. (Accessed 15 June 2013).

Stefanović, S. (2008). Analytical framework of FDI determinants: Implementation of the OLI model. Economics and Organization, 5(3), pp. 239-249.

Te Velde, D.W. (2006). Foreign Direct Investment and Development: An historical perspective. UNCTAD.

The Financial Times: FDI Markets. (2012). FDI Markets: Crossborder Investment Monitor. [Online] Available: http://www.fdimarkets.com/. (Accessed 15 June 2012).

UNCTAD (United Nations Conference on Trade and Development). (2010). World Investment Report: Investing in a low-carbon economy. New York: United Nations.

White, C \& Fan, M. (2006). Risk and Foreign Direct Investment. Palgrave Macmillan.

World Bank. (2012a). World Development Indicators. [Online] Available:

http://databank.worldbank.org/data/views/variableSelection/selectvariables.aspx? source=worlddevelopment-indicators. (Accessed 15 December 2013).

World Bank. (2012b). World Bank Good Governance Indicators. [Online] Available: http://data.worldbank.org/data-catalog/worldwide-governance-indicators. (Accessed 15 December 2013) 
World Bank. (2012c). World Bank Commodity Prices. [Online] Available:

http://data.worldbank.org/data-catalog/commodity-price-data. (Accessed 15 December 2013) 
APPENDIX: (Al/ results are authors'own calculations)

\section{Factor analysis}

\section{Risk factor analysis}

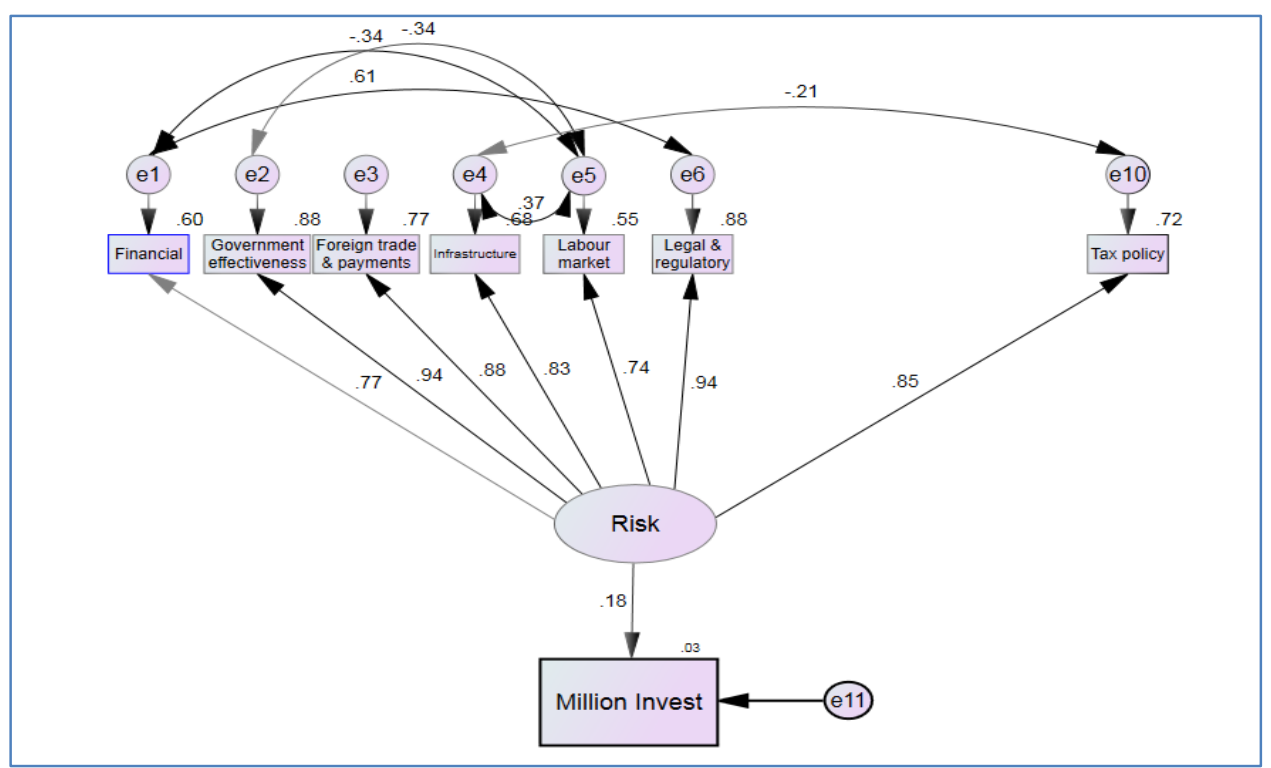

\section{Good governance factor analysis}

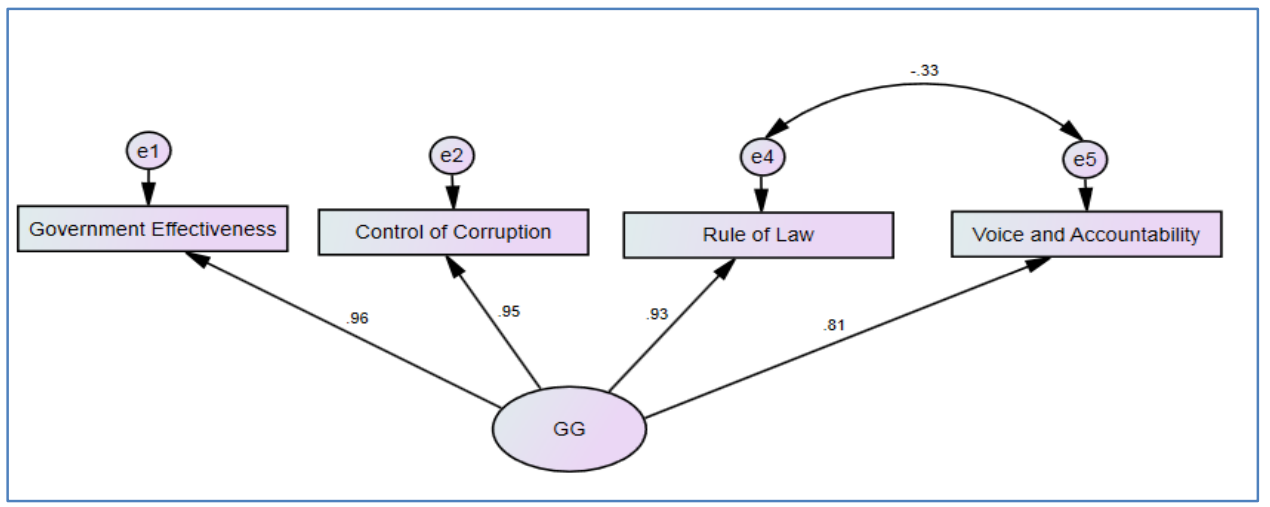




\section{Global factor analysis}

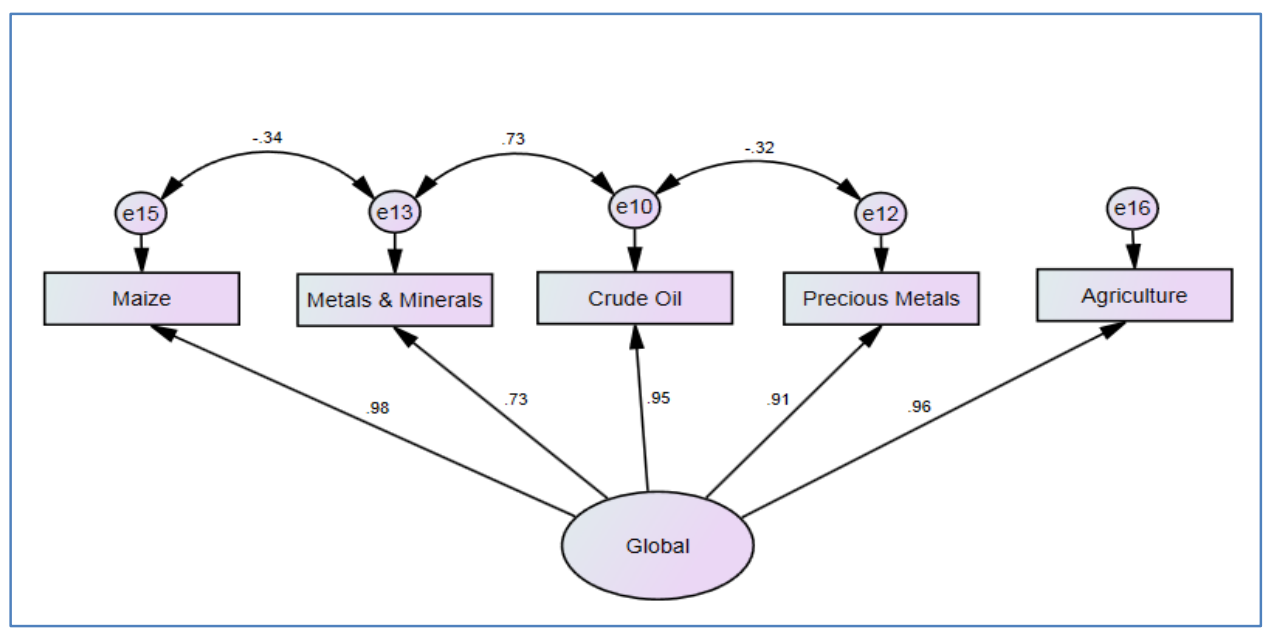

\section{Macroeconomic factor analysis}

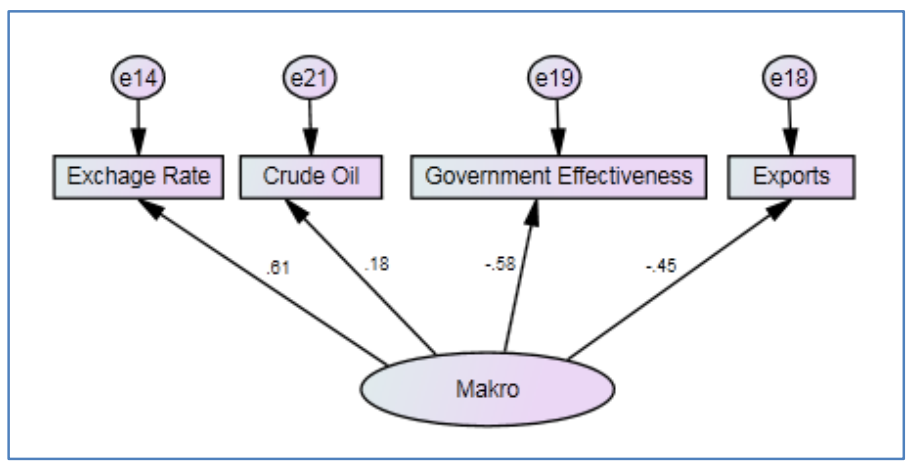

\section{Microeconomic factor analysis}

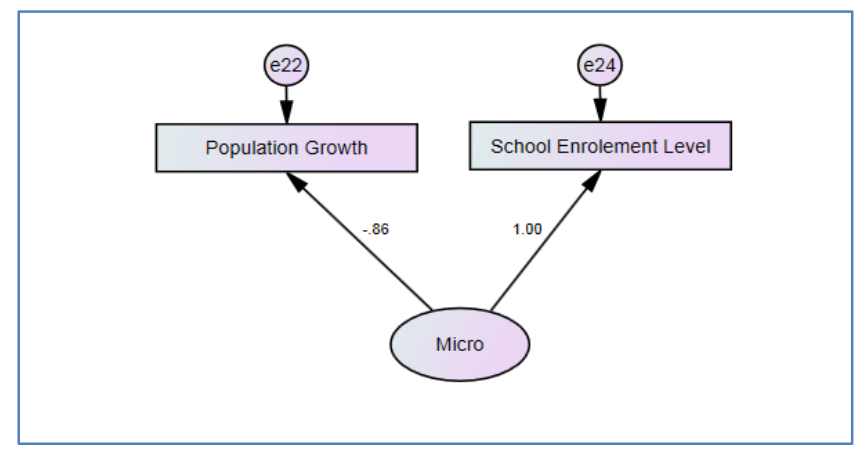


Bezuidenhout, Cloete \& Claassen

Factor analysis measures

\begin{tabular}{lcccccc}
\hline Factor analysis & Chi-Square & RMSEA & CMIN/DF & NFI & IFI & CFI \\
\hline Risk factors & 44.09 & 0.087 & 2.939 & 0.978 & 0.985 & 0.985 \\
Good governance & 1.93 & 0.059 & 1.93 & 0.998 & 0.999 & 0.999 \\
Global factors & 6.597 & 0.092 & 3.299 & 0.997 & 0.998 & 0.998 \\
Macroeconomic factors & 15.199 & 0.156 & 7.599 & 0.821 & 0.841 & 0.824 \\
Microeconomic factors & 0 & 0.519 & 0 & 1 & 1 & 1 \\
\hline
\end{tabular}

\section{Regression analysis}

\section{Good governance regression analysis}

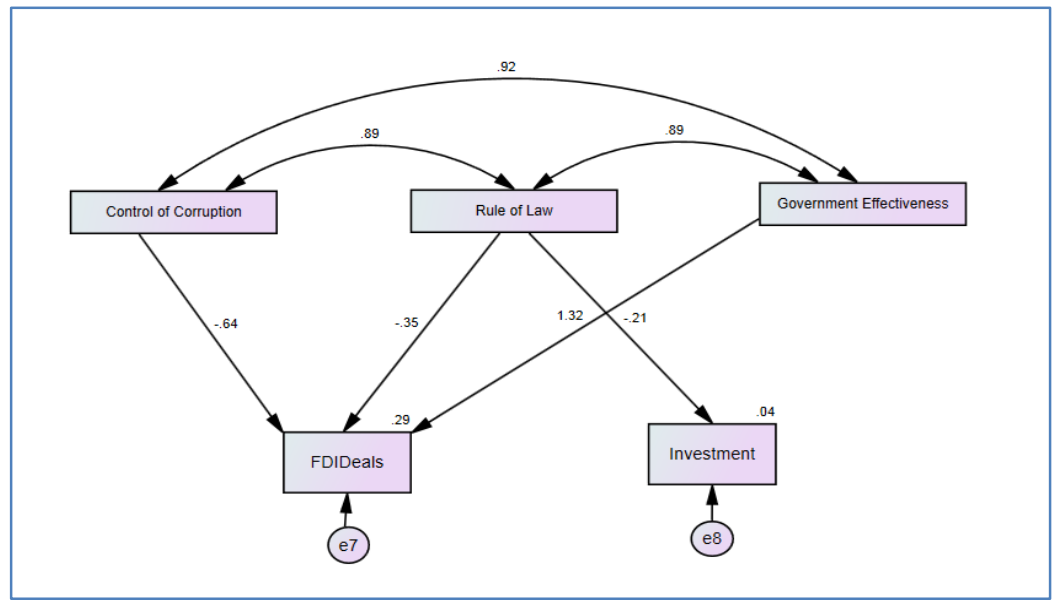

\section{Global regression analysis}

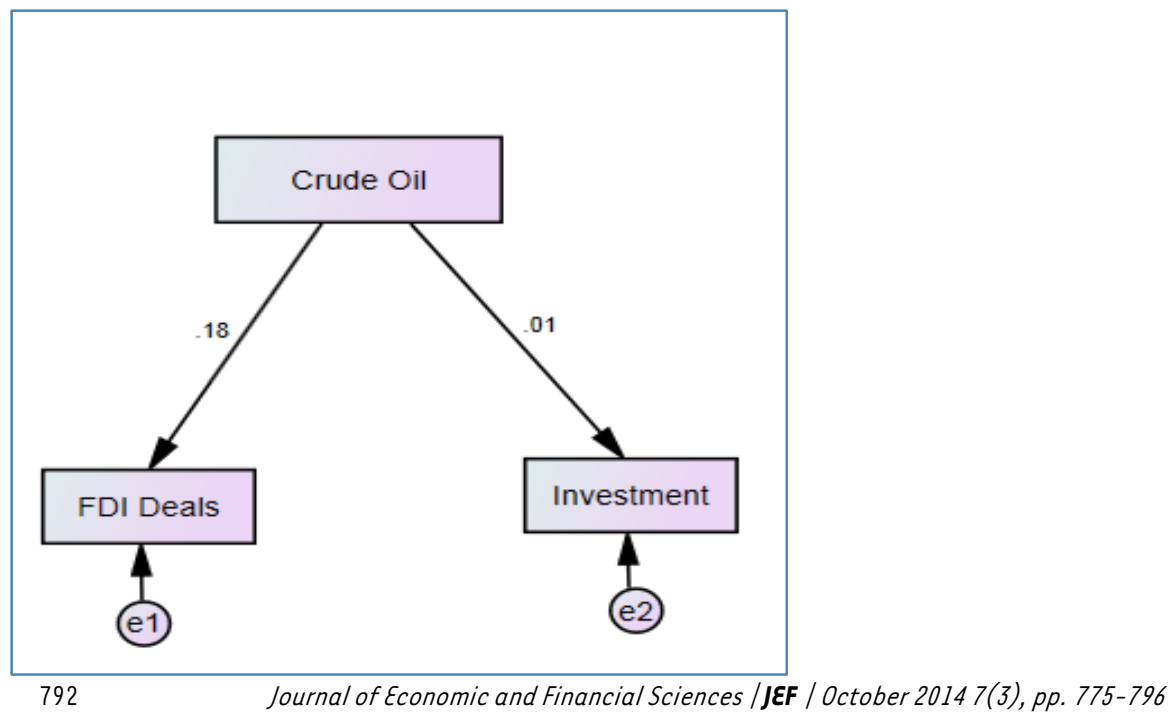




\section{Macroeconomic regression analysis}

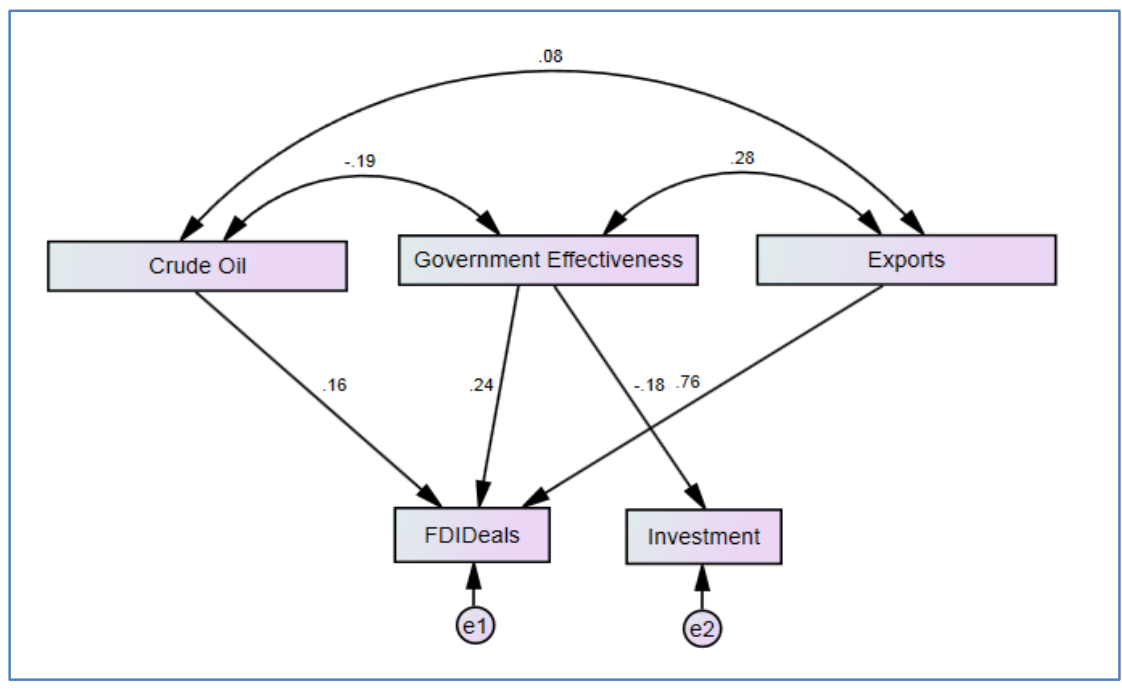

\section{Microeconomic regression analysis}

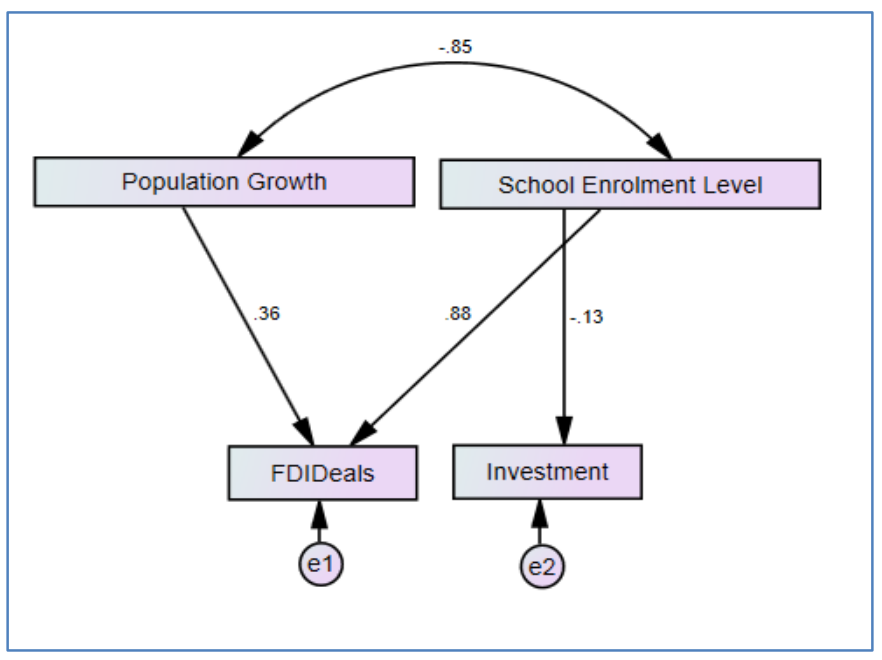


Bezuidenhout, Cloete \& Claassen 